\author{
Dossiê \\ TRIBUNAL DO SANTO OFÍCIO PORTUGUÊS, 200 ANOS APÓS EXTINÇÃO: \\ HISTÓRIA E HISTORIOGRAFIA
}

\title{
HOMENS PROFANOS: FLUIDEZ IDENTITÁRIA ENTRE RENEGADOS "PORTUGUESES” NA ÍNDIA (C.1540-1612)
}

\author{
PROFANE MEN: IDENTITY FLUIDITY AMONG "PORTUGUESE" RENEGADES IN \\ INDIA (C. 1540-1612) \\ Eduardo Borges de Carvalho Nogueira*
}

\begin{abstract}
RESUMO
O presente artigo oferece análise a respeito de trajetórias de três homens categorizados como apóstatas renegados pelo Santo Ofício de Goa. Súditos da Coroa portuguesa, tais homens, que viveram na Índia a partir de meados dos Quinhentos, aventuraram-se para além dos limites da entidade imperial luso-asiática, o Estado da Índia. Partindo para o Decão, no interior do subcontinente indiano, serviram a sultões, lutaram a favor destes contra portugueses, tornaram-se muculmanos, assumiram aparência de iogues e retornaram à Cristandade lusitana. Neste contexto, metamorfosearam-se em outros para sobreviverem a duras condições de vida, bem como para escaparem de algozes. De modo a compreender como se deram tais transformaçôes, sobretudo, quanto à identidade dos três renegados, cujas experiências foram analisadas pelo presente artigo mais detidamente a partir de documentação inquisitorial, foram utilizados os conceitos de sagrado e profano de Giorgio Agamben como principais instrumentos teóricos.
\end{abstract}

PALAVRAS-CHAVE: Estado da Índia. Renegados. Identidades.

\begin{abstract}
The following paper offers an analysis about trajectories of three men categoryzed as renegades apostates by the Goan Inquisition between the end of 16 th century and the begining of 17 th century. Portuguese Crown subjects, such men, who lived in India from mid 16th century, ventured beyond the limits of the Luso-Asiatic imperial entity, the Estado da India. Going to the Indian inland of Dekan, they served sultans, fought for them against Portugueses, became muslims, took on yogin semblances and returned to the Lusitanian Christemdom. In this context they metamorphized themselves in others to survive to the hard conditions, as well as to escape their executioners. To comprehend how those transformations ocurred in these renegades identities, Giorgio Agamben's concepts of sacred and profane were used as theoretical instruments. Their experiences were closely analysed by this thesis based on inquisitorial documents.
\end{abstract}

KEYWORDS: Estado da Índia. Renegades. Identities.

O estudo de casos a seguir, fruto de pesquisa para elaboração de tese de Doutorado, não tem como objetivo rastrear minuciosamente os passos daqueles que aqui são objeto. Ainda que dados levantados a respeito de suas atribuladas vidas a partir de documentação inquisitorial venham a ser

\footnotetext{
* Professor do Departamento de História do Colégio Pedro II, Rio de Janeiro. Doutor em História Social pela Universidade Estadual do Rio de janeiro (UERJ). Email: ebcnogueira@gmail.com
} 
usados, o serão como base para a análise da trajetória destes homens a partir dos conceitos de "sacralização" e "profanação" (AGAMBEN, 2007), em diálogo com os de "transgressão" (FOUCAULT, 2009) e "tática" (CERTEAU, 2014). Logo, serão privilegiados os momentos nos quais são identificáveis os pontos de ancoragem destes em meio aos seus caminhos e desventuras entre Portugal e o sul da Ásia.

Assim, serão apresentados trechos das tortuosas vidas destes homens em que foram identificados fenômenos, sobretudo, identitários, os quais permitiram a aplicação dos conceitos em tela. Qualificam-se suas vidas como tortuosas, mas, tendo em vista suas muitas transformações táticas em busca de sobreviver em meio a paragens e situações diversas, podem ser mais propriamente qualificadas como profanas.

\section{ANTES DA ÍNDIA E ANTES DA PROFANAÇÃO}

Em dezembro de 1565, a pedido do inquisidor do Santo Ofício de Goa, Aleixo Dias Falcão, compareceu diante deste António Camacho. Colocado sob a condição de réu, ele respondeu às muitas das perguntas a seu respeito lançadas por aquele, ainda que não soubesse exatamente o motivo pelo qual fora para ali chamado. Talvez suspeitasse de vários, afinal, sua vida ao longo dos nove anos anteriores tinha sido, no mínimo, heterodoxa para alguém como ele, um cristão-velho.

Às perguntas referentes às suas origens, afirmou ter nascido em Lisboa, tendo sido batizado na Sé, perto da qual viveu com seus pais junto à Porta de Ferro. ${ }^{1}$ Filho de pais "ambos portugueses cristãos velhos sem outra mistura" 2 , herdou destes a condição cristã-velha, pertencendo, portanto, ao grupo étnico, social e político dominante no Reino Quinhentista. Herdou de seu pai as letras e o ofício que, mais tarde, exerceria: mestre-escola.

Prosseguindo com o ofício de seu progenitor, António se casou com Ana das Covas, com a qual passou a viver na "rua dos albardeyros junto do hospital del rei". ${ }^{3}$ Situado, portanto, próximo ao Rossio, ele ergueu nova escola em uma área, aliás, situada em meio a importantes redes lisboetas. Atuando como mestre-escola em meio à década de 1550, ou seja, em meio às primeiras e explosivas décadas de implantação de uma rígida concepção de religiosidade católica sobre o império português, Camacho pode ser entendido como uma das muitas peças de implantação dos projetos de disciplinamento social em vigor neste período. Recuperando Palomo (2006, p. 74), este afirma que a alfabetização infantil, área mais provável de atuação daquele, vinha acompanhada de lições rudimentares da fé a partir de textos religiosos utilizados como literatura básica gramatical.

António Camacho, enquanto foi mestre-escola, portanto, colaborou para a aplicação dos projetos encabeçados por Coroa e Igreja portuguesas, que visavam instituir maior enrijecimento identitário sobre seus súditos e fieis. Instituição, pois, de um processo de "sacralização" identitária mais incisivo e marcado

\footnotetext{
${ }_{1}$ Arquivo Nacional da Torre do Tombo, Tribunal do Santo Ofício, Inquisição de Lisboa [doravante ANTT, TSO, IL], Processo 5562, fl.3.

2 ANTT, TSO, IL, Processo 5562, fl.3.

3 ANTT, TSO, IL, Processo 5562, fl.3.
} 
pela maior presença do Estado na condução das maneiras pelas quais aqueles que estavam sob seu mando eram construídos.

Contudo, curvas bruscas nos caminhos que acabou por adotar revelam possibilidades de enxergálo não exatamente como um reprodutor das regras dos poderes aos quais estava submetido. Mas talvez como alguém, ao menos potencialmente, até mesmo avesso a aspectos delas. Ainda em seu primeiro depoimento à mesa do Santo Ofício goês, ele afirmou ter partido de Lisboa para Goa em 1556, deixando para trás sua esposa Ana das Covas, não sendo explicitados os motivos que o levaram a tomar esta decisão. Da capital do Estado da Índia partiu, em seguida, para Chaul e, desta, para São Tomé de Meliapor.

Nesta última localidade, Camacho contraiu matrimônio com a mestiça Joana Marsada, ${ }^{4}$ Com isso, portanto, aos olhos das leis e valores do império, António tornava-se bígamo, ainda que tanto a família de sua nova cônjuge quanto o sacerdote oficiante e testemunhas de seu casório desconhecessem que o noivo estava incorrendo neste crime. Inicialmente o réu declarou à mesa que, ao casar pela segunda vez, não sabia se sua primeira esposa era viva ou morta, o que pode ter sido uma tentativa, de sua parte, de dar a entender que não tinha plena consciência da condição de Ana das Covas.

Mais à frente em seu processo, no entanto, Camacho acabou afirmando que, face às dificuldades de sobrevivência inicial nas terras luso-indianas, acabou por aceitar a proposta de casamento feita pela família de Joana. E que teria sido já a terceira família, desde sua estadia em Chaul, que o procurava com o mesmo fim. Interessante dado, pois revela que, ainda que ele fosse um recém-chegado a estas terras, ele, reinol, letrado e desejoso de instituir uma nova escola, atraiu atenção positiva a seu respeito. Afirmando aos inquisidores que negara as duas primeiras propostas, diante da terceira, "por remediar sua necessidade porquanto lhe deram teto com a dita Joana Mansada" 5 , e em vista do bom dote que lhe oferecia a família desta, acabou por aceitar, alegando a esta ser solteiro.

“Taticamente”, então, António Camacho tornou-se um "casado" do Estado da Índia. Condição, aliás, favorável, pois lhe possibilitava, por um lado, envolvimento legítimo com a parcela da população lusa que podia operar às claras com as instâncias formais do império português. E, por isto, beneficiado pelos ganhos a receber do Estado por ingressar neste grupo, tais como pequeno lote de terra, que, junto ao dote recebido pelos familiares de sua nova esposa, podem ter criado condições para que ele abrisse em São Tomé sua nova escola.

Assim, sua tática consistiu em ocultar sua condição de previamente casado em Lisboa para poder estabelecer-se de modo mais estável em São Tomé de Meliapor. Burlava, talvez intencionalmente, o tabu e a regra referentes à bigamia entre católicos, vigente nos domínios lusos de então. Paira a dúvida sobre a consciência de seu delito, já que, ao explicar-se à mesa da Inquisição de Goa, revela inconsistências em seus argumentos, sobretudo ao alegar não ter conhecimento sobre sua antiga esposa após ter embarcado para a Índia, permitindo-se contrair mais um matrimônio.

${ }^{4}$ ANTT, TSO, IL, Processo 5562, fl.4.
5 ANTT, TSO, IL, Processo 5562, fl.9. 
Conforme visto antes, contudo, afirmou também ter se casado em vista do dote, de modo a facilitar-lhe a sobrevivência. Logo, ocultou o fato de talvez não ser viúvo e a certeza de que solteiro não era. Evidente fica, pois, que jogou em seu favor com as regras referentes ao casamento. Parafraseando Berger, “só quem conhece as regras do jogo está em condições de trapacear" (BERGER, 2001, p. 168). Ao que tudo indica, portanto, Camacho provavelmente conhecia, mesmo que superficialmente, os impeditivos e perigos ligados à condição de bígamo, e, de modo a evitá-los, "trapaceia", garantindo sucesso em sua sobrevivência na Índia.

Durante cerca de um ano ele viveu sob estas condições, coabitando com Joana Marsada, até 1562 ou 1563, mantendo-se como mestre-escola em Meliapor. Cidade, aliás, central nos fluxos de "portugueses" entre Coromandel, Bengala e Pegu, o que possivelmente lhe abriu caminho para mais uma porção do império: Malaca. Sendo dito somente que para lá foi "negociar sua vida"6, é afirmado em seu processo que foi nesta cidade que sua condição de bígamo foi exposta. Descoberto pelo bispo local, Camacho acabou preso e despachado em uma nau de banda, da qual escapou em Coulão. Lá, entretanto, já estavam membros da família Marsada dispostos a prendê-lo, o que fez António fugir para o interior do Decão e iniciar outras táticas de sobrevivência.

\section{EM MEIO AO DECÃO}

O ingresso às terras do interior indiano, a partir de Coulão, entre os anos de 1563 e 1564, deu início a uma longa e atribulada jornada na vida de Camacho. Segundo seu processo, neste período adentrou pelo reino hindu de Vijayanagar, de onde, então, partiu para o "Inyza Maluqo de quem tomou moxara e o serviu algum tempo andando à portuguesa".7 Esta afirmação feita ao tribunal indicava que o réu, foragido das justiças portuguesas, passou a estabelecer relações de dependência com o sultão de Ahmadnagar.

O recebimento da moxara, segundo o réu teria afirmado, se dava mediante a prestação de serviço ao sultão, no caso, Husain I, da dinastia Nizamshahi. Sendo Camacho um fugitivo das justiças portuguesas, ao recorrer ao soberano de Ahmadnagar, o fez de modo a obter meios para sobreviver, oferecendo-se àquele em uma das formas que interessariam a um sultão: ter em meio às suas forças um firangi luso como homem de armas. Condição evidenciada ao longo do processo, ao que parece, Camacho, para além de ser um homem letrado, também tinha conhecimentos a respeito do manejo de armas. Aspecto frequente entre os renegados firangi dispersos pelos muitos reinos do sul asiático, ele o compartilhava com outros dois réus aqui analisados: Jorge Cardozo de Mendonça e Gonçalo Toscano.

No caso de Mendonça, também réu do Santo Ofício em finais dos Quinhentos, segundo o documento a respeito de seu caso, ele teria afirmado à mesa inquisitorial que, "induzido" por um obscuro

\footnotetext{
${ }^{6}$ ANTT, TSO, IL, Processo 5562, fl.6.
}

7 ANTT, TSO, IL, Processo 5562, fl.6. 
rei de Barpocha, tornou-se mouro, inclusive sofrendo a circuncisão, tomando "traje de mouro e vivendo como tal", bem como executando as cerimônias do grupo ao qual se filiou por certo período de sua vida.

A menção à "indução" não deixa claro se houve alguma pressão mais ou menos ostensiva da parte muçulmana sobre o réu para que ele tenha apostatado. Contudo, alegar à mesa que foi "induzido" a tomar tal decisão poderia ser uma "tática" frente aos inquisidores. Afinal, com esta alegação o réu poderia tentar afastar de si a suspeita de ter apostatado espontaneamente e por sua própria vontade, o que poderia agravar sua situação diante do tribunal.

Tenha sido por seu livre-arbítrio ou não, Mendonça, então, assumiu pela primeira vez, segundo sua sentença, os sinais externos, de modo a ser identificado como muçulmano. Sob as ordens do rei de Barpocha conduziu tropas islâmicas, ocupando a função de condestável-mor, papel que desempenhou mais tarde junto às forças de Bijapur: "servindo ao dito rei de condestável-mor e depois de haver alguns anos que estava em seu serviço, se passou à cidade de Visapor, onde serviu o Hidalcão". ${ }^{8}$

Gonçalo Toscano, outro renegado que caiu nas malhas do Santo Ofício goês, no século XVI, também serviu a forças islâmicas. Em seu processo é explicitado que ele teria lutado junto às tropas de Ahmadnagar contra cristãos. Não alega ter sido induzido a apostatar, conforme Mendonça o fez, mas apresentou à Mesa as duras circunstâncias que o teriam levado a agir desta forma.

Serviu às tropas de Ahmadnagar mediante a expectativa de poder sobreviver com aquilo que, em meio a estas, recebesse como soldo ou como direito de butim nos conflitos ocorridos em diversas partes da Índia, na segunda metade dos Quinhentos. ${ }^{9}$ A alegação junto ao tribunal, de que teria apostatado em benefício de sua própria sobrevivência, pode ser sinal de um fator importante no fluxo de homens cristãos para as fileiras islâmicas.

O caso de Mendonça, ainda que aponte para circunstâncias diferentes, converge com o de Toscano quanto à ameaça à sua vida como causa para realizar mais uma apostasia. Anos mais tarde, partindo para Baçaim e lá tendo sido absolvido por certo padre no Colégio de São Paulo, voltou, por razões não identificadas, às terras de Bijapur. Nelas, uma vez sob a ameaça de ser preso pelas forças do sultão por, sendo solteiro e em trajes de cristão, viajar com uma obscura mulher muçulmana casada, tornou-se mouro pela segunda vez em sua vida, ao menos segundo sua sentença de princípios do século XVII..$^{10}$

Anos depois, alegando arrependimento por seus atos como infiel, apresentou-se à mesa do Santo Ofício de Goa em 1590. Abjurando publicamente seus erros em auto-de-fé na sé goesa, em dezembro deste ano, foi reconciliado ao seio da Igreja. Foi despachado no ano seguinte para Lisboa, onde cumpriria sua pena, contudo, durante a viagem, deparou-se com uma tormenta na costa leste africana. Ainda que escapando com vida, não retornou às terras sob jugo luso, seja na África ou na Ásia, mas buscou auxílio

8 ANTT, TSO, IL, Processo 5562, fl. 49.

9 ANTT, TSO, IL, Processo 4931, fl. 8-9.

10 ANTT, TSO, IL, Processo 4938, fl.49. 
mais uma vez em Bijapur, "onde logo, de sua própria e livre vontade, sem medo nem força alguma, tomou touca e cabaia e nome de mouro". ${ }^{11}$

Ainda que a letra inquisitorial tenha preservado a interpretação de que, nesta quarta apostasia, Mendonça a teria feito deliberadamente, paira a desconfiança acerca disto, visto que suas condições após sobreviver a tamanha tempestade são obscuras. Talvez em meio às agruras de sua escapatória tenha sido levado às praias de Bijapur, onde, uma vez que lá já havia vivido, poderia residir mais uma vez como muçulmano. Levando-se em conta que, a partir do momento em que escapou do naufrágio, deveria ter se apresentando ao Santo Ofício, por não fazê-lo, caía na condição de fugitivo, o que pode tê-lo pressionado a voltar à Umma.

Camacho, Mendonça e Toscano, portanto, apresentaram aos inquisidores e deputados argumentos semelhantes como causas para, ao menos, uma de suas apostasias em direção ao Islã: a sobrevivência. Fome, ameaças de prisão pelas forças portuguesas, fuga de desastre e ameaças da parte islâmica são apontadas como circunstâncias, em meio às quais teriam ingressado como muçulmanos em comunidades dirigidas por forças islâmicas. Elementos, portanto, de ordem material plausíveis em meio às realidades índicas dos séculos XVI e XVII, marcadas por conflitos entre diferentes soberanos, perseguições, tensões de diferentes ordens e viagens marítimas.

Entretanto, tais fatores devem ser colocados em perspectiva, pois podem, também, ser sinais de táticas frente à Inquisição. Pois, por mais que as adversidades por eles relatadas possam ter ocorrido de fato, elas podem ter sofrido exageros da parte de seus narradores na condição de réus. Visto que sua posição diante dos inquisidores e deputados era de grande vulnerabilidade, talvez uma forma de amenizar sua desvantagem fosse a manipulação da narrativa dos fatos em seu favor. Logo, o exagero quanto às circunstâncias que os levaram à apostasia poderia ser uma tática, com intuito de obter misericórdia da parte dos juízes. Assim como o recurso ao argumento de que foram forçados a apostatar. Novamente, não se pretende aqui diminuir ou negar tal fato, presente em outros documentos analisados ao longo da presente pesquisa e em obras historiográficas a respeito das tensões entre cristãos e muçulmanos, seja no Índico ou no Mediterrâneo. Contudo, coloca-se aqui em dúvida o quão táticos eram estes réus ao afirmarem que foram forçados a adotar o Islã como sua nova fé.

Pelo fato de a Inquisição amenizar as penas daqueles que alegassem ter sofrido ameaças que os levaram a cometerem a apostasia (TAVARES, 2002, p. 212), caso eles tivessem conhecimento deste importante fator a seu favor, não o utilizariam em benefício próprio? E ainda que o segredo imposto a todos os que fossem processados pelo tribunal limitasse o conhecimento da parte dos fiéis sobre seus trâmites, não haveria rachaduras nesta determinação?

Talvez o caso de Jorge Cardozo de Mendonça traga à tona possíveis indícios de atitudes táticas frente ao tribunal. Tendo sido ele apóstata "relapso" de fato, pois por três vezes retornou à Umma, ainda que tenha sofrido, segundo sua sentença, a pena capital em 1591, é considerável sua capacidade de livrar-

11 ANTT, TSO, IL, Processo 4938, fl.50. 
se do Santo Ofício. Apresentando-se a este ora voluntariamente, ora coercitivamente, a fonte a seu respeito indica que pediu perdão ao ponto de convencer seus juízes de seu arrependimento, chegando mesmo a ser despachado para Lisboa, conforme visto antes, mesmo que sem êxito no cumprimento do objetivo da viagem.

Narrando, na maioria de seus depoimentos, que sob duras conjunturas foi levado a tornar-se mouro, seja induzido por um soberano muçulmano, seja por ter sido ameaçado por "infiéis", pode ter obtido olhar não tão severo em suas primeiras confissões à mesa de Goa. Somava a isto a fala de que nunca havia deixado de ser cristão em seu coração, bem como arrependia-se de ter executado ritos islâmicos, crendo que "a lei de Mafamede era boa" tanto quanto a de Cristo. ${ }^{12}$ Expressão amalgamada de suas possíveis crenças, talvez tenha sido vocalizada à mesa em atitude de humilhação e "visível arrependimento", posturas valorizadas pela Inquisição e entendidas como sinais de que "aquela ovelha poderia ser retornada ao rebanho".

Posturas, por sua vez, que consistiam em uma comunicação verbal e não verbal entre réu e juiz. Caso aquele tivesse a capacidade de usar conscientemente tal código em seu benefício, esperando efeitos concretos sobre este, as possibilidades de retirar-se do tribunal com penas amenas poderia ocorrer. Tática, portanto, que poderia ser de uso corrente em meio àqueles que ainda não haviam sido levados à pena capital, caso de Mendonça até certo ponto de suas desventuras. Afinal, por quatro vezes deparou-se com a Inquisição ou com algum representante desta, conseguindo, em suas duas primeiras apostasias, receber o perdão, enquanto na terceira recebe como pena o malogrado degredo.

Esta hipótese, contudo, não desmerece o peso das determinações protocolares do próprio tribunal: segundo Lipiner (1977), consideravam-se brandamente os casos de primeira ocorrência de crime da parte do réu, não sofrendo penas graves, receberia, após confissão de suas culpas, admoestação da parte do tribunal. Em casos de primeira relapsia, os réus poderiam receber o benefício da "segunda reconciliação"; caso o réu alegasse, como causa de seu desvio da fé católica, alguma violência, ele também poderia ser readmitido pelo tribunal (LIPINER, 1977, p. 118-119).

Logo, Mendonça pode ter recebido o beneplácito do perdão da parte dos inquisidores quanto à sua primeira ocorrência como apóstata, recebendo apenas admoestação, o que também pode ser deduzido dos casos de Toscano e Camacho. Assim como podem, tanto Mendonça quanto Camacho, ambos relapsos, também terem sido reconciliados segundamente graças à determinação joanina, que assim exigia que fossem conduzidos os casos que apresentassem uma primeira relapsia. Também pode ter sido Mendonça beneficiado por ter alegado que foi pressionado violentamente a tornar-se mouro em uma de suas passagens pelo Santo Ofício de Goa.

Ainda assim, da parte deste réu, para que alcançasse duas liberações mediante admoestações e um degredo, mesmo tendo incorrido no mesmo delito anteriormente, é provável que sua capacidade de convencimento fosse razoável. Afinal, aparentemente convenceu seus juízes de que fora forçado a

12 ANTT, TSO, IL, Processo 4938, fl.50. 
apostatar duas vezes, bem como é provável que fosse convincente em sua habilidade de demonstrar arrependimento diante da Mesa.

Portanto, por mais que se considerem os trâmites formais do Santo Ofício, Mendonça parece ter feito uso tático de certos parâmetros de comunicação com aquele quando se encontrava na situação de réu. Talvez usando o artifício do exagero quanto às agruras de sua vida que o levaram a apostatar, talvez intensificando, emulando ou sendo expressivamente honesto em sua postura de arrependimento, ele conseguiu escapar de penas maiores ao menos em metade de suas passagens pela Inquisição.

Camacho, Mendonça e Toscano, portanto, possuem um notório ponto de convergência: os três alegaram ao Santo Ofício que apostataram mediante as dificuldades e pressões das vidas que levavam. Beneficiados pelos trâmites do Tribunal quanto à ocorrência de seus casos e suas reincidências nos delitos em questão, exceto Mendonça, sobreviveram ao juízo inquisitorial. Paira, contudo, a dúvida, sobretudo quanto ao caso daquele que recebeu pena máxima: o quão táticos foram eles diante dos juízes e deputados, manipulando suas narrativas em benefício próprio? Assumiram eles posturas que induzissem o tribunal a amenizar suas penas?

Será difícil elucidar a contento tais questões, visto tanto a exiguidade de fontes quanto o acesso às falas dos réus ser razoavelmente bloqueada pela forte presença dos discursos do Santo Ofício na documentação processual por ele elaborada. Isto não impede, contudo, de serem levantadas, a partir desta documentação, questões semelhantes às anteriormente feitas, mas agora no que diz respeito à vivência dos réus nos domínios islâmicos. Teriam eles manipulado taticamente elementos que lhes foram impostos nas terras dos sultanatos?

Afinal, se Camacho, Mendonça e Toscano apostataram da fé cristã para a islâmica e vice-versa, é possível refletir a respeito do quão pragmaticamente podem eles ter adotado a aparência e outros sinais externos de aderência a ambos os credos. É necessário, contudo, ter em mente o cuidado para não conduzir a presente reflexão para possíveis "insinceridades" dos réus, seja para com um credo ou para com o outro.

Ainda assim, é possível levantar hipóteses e inferências a partir daquilo que ficou registrado em seus processos e nas sentenças de seus relatos a respeito de suas desventuras pela Índia. A começar pela aparência dos três: de seus relatos foi registrada a alteração de seus trajes, antes "de cristãos" e, tornados "mouros, foram levados a tomar "touca e cabaia". Elemento distintivo na conflitiva realidade índica da segunda metade do século XVI e princípios do XVII, a indumentária indicava visualmente as filiações religiosas e políticas daquele que a portava às comunidades pelas quais circulava.

Assim, as identidades presentes neste ambiente eram externadas a partir de sinais aparentes e facilmente detectáveis. Fossem a touca e cabaia, os trajes cristãos ou os elementos estético-ritualísticos dos grupos "hindus", denotavam filiações. Logo, adotando as vestes de mouros, os réus transmitiram, aos olhos das comunidades pelas quais circulavam, sobretudo as islâmicas, nas quais, no momento de suas passagens à Umma, se encontravam, a imagem de que se tornavam membro desta. 
Bem como no trânsito inverso: ao utilizarem trajes à portuguesa, obtinham acesso às comunidades lusas espalhadas para além dos domínios oficiais do Estado da Índia. Por exemplo, Gonçalo Guedes de Revoredo, testemunha no processo de Camacho, afirma que tanto este como ele próprio, de modo a ingressarem em grupo de prováveis mercenários renegados lusitanos a serviço do sultão de Ahmadnagar, passaram a andar com trajes reconhecidamente portugueses. O que indica, por sua vez, que antes ambos, companheiros temporários de viagens segundo o processo em questão, faziam uso de outras vestimentas, no caso, de mouros..$^{13}$

E para além das indumentárias gerarem ancoragens possíveis em meio aos grupos e situações às quais eram condizentes, seu uso inadvertido em meio a certos ambientes e situações podia oferecer perigo aos seus portadores. Jorge Cardozo Mendonça, conforme ficou registrado em sua sentença, apresentou em sua narrativa ao Santo Ofício indícios que permitem ter noção deste fato. ${ }^{14}$

Em seu último depoimento à Inquisição, são sinalizadas as contradições na vida de Mendonça que o levaram a ser conduzido diante dos juízes pela quarta vez, tais como viver em meio aos muçulmanos de Chaul de Cima e se apresentar como cristão em vestes reconhecidamente muçulmanas. Tais aspectos, aos olhos de outros cristãos, levou-os a desconfiarem da palavra do réu, cuja aparência revelava mais vínculos com a realidade islâmica do que com a cristã. Soma-se a isto o fato de Mendonça ter alcançado, já em idade avançada, certa estabilidade, através do cultivo de sua horta, em meio aos muçulmanos de Bijapur, o que poderia ser indicativo de envolvimento por livre vontade com estes.

Já no caso de Gonçalo Toscano, o uso das vestes cristãs em ambiente islâmico foi-lhe penoso por fazer-lhe merecedor de desprezo da parte da população moura dos arredores de Baçaim. Tendo chegado a este local fugindo daqueles que o acusavam de roubo, Gonçalo avançou pela área sob controle islâmico vizinha àcidade portuguesa em "trajo de cristão". 15

Em fuga da realidade luso-indiana e em meio a condições adversas mesmo em terras islâmicas, Toscano optou pela adoção do Islã como marcador de sua identidade político-religiosa na esperança de obter meios para sobreviver. Contudo, para efetuar tal transformação, foi-lhe necessário assumir aparência que viabilizasse sua entrada à comunidade à qual pretendia ingressar.

Afinal, o fato de estar com trajes cristãos pode ter dificultado a obtenção de víveres junto aos muçulmanos dos arredores de Baçaim, visto que em meio a estes, ainda com trajes portugueses, não encontrava "quem lhe desse de comer". De modo a remediar tal situação, ele foi à busca da liderança do arraial, o qual o aceitou, conferindo-lhe o "salvo- conduto" para ingressar na comunidade, ou seja, receber a touca e cabaia.

Nos casos acima, portanto, verifica-se a imposição de trajes islâmicos como forma de elaboração de aparência que viabilizasse identificação, e, com isso, ingresso nas comunidades sob domínio

\footnotetext{
13 ANTT, TSO, IL, Processo 5562, fl. 54-55.

14 ANTT, TSO, IL, Processo 4938, fl. 50-51.

${ }^{15}$ ANTT, TSO, IL, Processo 4931, fl.7-8.
} 
muçulmano. Depreende-se, portanto, que nos casos em que tal imposição é identificada, a busca por sobrevivência da parte dos réus foi um fator na sua submissão aos parâmetros identitários que incidiam sobre a aparência dos membros da comunidade em que pretendiam ingressar.

Aparência a qual deveria remeter à reconstrução evidente de suas filiações político-religiosas quando fora das terras sob jugo lusitano. Não é por menos que, nos casos em que ocorreu apostasia em direção ao Islã, um dos primeiros passos de admissão à Umma era justamente a obtenção da touca e cabaia a partir das mãos da autoridade muçulmana local.

O caso de Camacho nos revela, contudo, que o uso dos trajes não necessariamente passava por relações coercitivas. Usos táticos também podem ter ocorrido, demonstrando a manipulação dos códigos de indumentária por aqueles que identificaram, decodificaram e esvaziaram os sentidos compartilhados por determinada população, utilizando tal elemento "profanamente".

Retornando ao depoimento de Revoredo sobre o mestre-escola lisboeta, ele afirma que, deliberadamente, Camacho trocou suas vestes de modo a ingressar no grupo de prováveis mercenários portugueses. Tal manipulação dos códigos de aparência e, logo, de demonstração de filiação políticoreligiosa, foram frequentes na jornada de Camacho pelo Decão. De modo a reduzir ameaças advindas do fato de ser compreendido como filiado ora aos cristãos, ora aos muçulmanos, o réu alterou por diversas vezes suas vestes.

No período em que António estava foragido das justiças portuguesas por motivos diversos daqueles que os levaram à primeira fuga, encontrava-se ele, então, a caminho de Ahmadnagar através de Chaul de Cima, e, em seguida, pelo sultanato de Bijapur. Enveredando por terras em guerra, Camacho, para além de perceber as ameaças comuns em momentos como este, percebeu-se como particularmente vulnerável devido ao fato de portar "hábito de cristão".

Reconhecendo que tal aspecto poderia atrair salteadores tanto "gentios" quanto muçulmanos, ao passar por Chaul de Cima, "comprou touca e cabaia e vestido de mouro com que foi até Abdnegue corte do Iniza Maluqo onde andou um mês e meio ou dois vestido à mourisca". ${ }^{16}$ Calculada e conscientemente, portanto, António lançou mão de código que lhe garantisse passagem mais segura por terras não portuguesas. Código que já conhecia desde antes de ser preso pela Inquisição, por volta de 1565, já que entre a fuga dos familiares de sua esposa Joana Marsada, no ano de 1564, e este momento sobre o qual nos debruçamos, ele já havia perambulado por Ahmadnagar e Golconda. E enquanto naquele sultanato conseguiu preservar sua "aparência de cristão" "andando à portuguesa" e recebendo moxara do Inizamaluqo como mercenário, neste outro a situação apresentou-se diferentemente.

Saindo de Ahmadnagar para Golconda, sultanato que apresentava, segundo o réu, mais segurança "por estar metido para a terra adentro onde menos portugueses vão"17, Camacho, apresentando-se ao Cotamaluqo em sua aparência de cristão português, pediu moxara em troca de serviços

16 ANTT, TSO, IL, Processo 4931, fl.22.

17 ANTT, TSO, IL, Processo 4931, fl.6.

Pol. Hist. Soc., Vitória da Conquista, v. 20, n. 1, p. 23-44, jan.-jun. 2021. ISSN 2236-8094 
ao sultão. Este lhe ofereceu uma proposta: o aceitaria caso se tornasse mouro. Em seu relato à Mesa, admitiu ter ficado em dúvida quanto à oferta, inicialmente não a aceitando e cogitando mais uma fuga.

Contudo, lá encontrava-se também na corte do sultão outro renegado, de nome João Perez, "mestiço de touca e cabaia". Este, percebendo o titubear de Camacho diante da oferta do Cotamaluqo, talvez tenha estabelecido com ele alguma identificação, visto que ambos outrora pertenceram ao Estado da Índia, eram falantes de português e, por conta destes elementos, talvez compartilhassem sentimentos de pertença à vaga comunidade de "portugueses" espalhada pela Ásia do sul.

Perez, então, aconselhou Camacho que fugisse ou que aceitasse a proposta de Ibrahim, sobretudo por conta do perigo que o rondaria caso não o fizesse enquanto estivesse em meio ao lascar do soberano. Camacho, então, teria realizado sua primeira apostasia, segundo seu processo ${ }^{18}$, momento no qual sofreu alterações estéticas consideráveis para além da indumentária. Desta forma. garantiu para si o conhecimento de códigos que the viabilizaram a sobrevivência em terras islâmicas por nove meses, nos quais também realizou ritos islâmicos. Ao fim deste período, alegando arrependimento do tempo que passara entre os mouros, retornou às terras sob controle luso, apresentando-se ao Santo Ofício de Goa.

O que nos leva de volta ao momento em que, de modo a efetuar a fuga das penas que the haviam sido impostas pelo tribunal, mobilizou deliberadamente os códigos de aparência que aprendera durante sua estadia em Golconda. Com objetivo de alcançar Ahmadnagar em segurança, abandonou a estética portuguesa, assumindo a muçulmana. Portando "vestido de mouro, touca e cabaia", chegou ao seu destino, onde se apresentou ao sultão em seu lascar de modo a, mais uma vez, obter moxara. Dele a obteve, vivendo como "mouro" por dois meses.

É provável, portanto, que, ao apresentar-se como mercenário muçulmano ao Iniz̧amaluqo e ao assumir pragmaticamente a identidade muçulmana "para os mouros que o vissem cuidassem que era mouro"19, o acesso a meios materiais que lhe garantissem asobrevivência tenha sido facilitado. A compreensão de tal metamorfose a partir da documentação disponível a seu respeito, contudo, apresenta lacunas: ainda que revele que Camacho praticasse alguns dos ritos islâmicos (salvo o Ramadão, que alegou à Mesa que nunca praticara), não deixa claro como se dava sua interação com os demais "mouros". Não são explicitadas suas relações cotidianas, de habitação e, raramente, de ocupação como homem de armas.

Logo, deduz-se que, vivendo por tantos meses em comunidades muçulmanas e, em meio a estas, compartilhando de ocasiões em que publicamente deveria mostrar-se como membro destas, caso dos ritos islâmicos, é provável que soubesse como se comunicar com esta população, ainda que não seja possível saber o quão eficazmente o fizesse. O que também se deduz do caso de Mendonça, visto que circulou por espaços islâmicos em diversos momentos de suas experiências pela Índia. De seu caso também é possível inferir algo semelhante quanto à manipulação de códigos para além da linguagem

18 ANTT, TSO, IL, Processo 5562, fl.7.

19 ANTT, TSO, IL, Processo 5562, fl.40.

Pol. Hist. Soc., Vitória da Conquista, v. 20, n. 1, p. 23-44, jan.-jun. 2021. ISSN 2236-8094 
verbal, pois, após sobreviver à tormenta que atingiu a embarcação em que se encontrava a caminho de seu degredo em Lisboa, partiu para Bijapur.

Assim como Camacho, Mendonça já tinha conhecimento dos procedimentos que deveria executar para que tivesse imagem e comportamento suficientemente convincentes para que fosse aceito na comunidade muçulmana à qual se dirigiu em Bijapur. Afinal, já havia por outras vezes vivido neste sultanato como mouro, inclusive, segundo sua sentença, seguindo "seus ritos e cerimônias, casando duas vezes com mulheres mouras ao seu modo, crendo de coração e vontade em Mafamede, tendo para si que ele era santo". ${ }^{20}$

Portanto, ambos, a partir das necessidades movidas pelas conjunturas, lançaram mão de elementos que garantissem segurança e sobrevivência em terras não cristãs. Ambos primeiramente apóstatas em virtude de pressões e ameaças sofridas em suas viagens iniciais pelo interior do Decão, garantiram, com isso, conhecimentos a respeito das comunidades em meio às quais viveram e circularam.

Pode-se afirmar que ao menos pragmaticamente assumiram traços e comportamentos distintos daqueles em meio aos quais foram primeiramente constituídos como súditos católicos de Portugal. Formação sacralizante para ambos: por um lado, de modo mais detalhado, sabemos que Camacho era, de modo mais evidente, como mestre-escola, produto dos processos de disciplinamento social em curso na Lisboa da segunda metade do século XVI.

Quanto a Jorge Cardozo de Mendonça, deste são dadas informações mais sucintas a respeito de seus vínculos com o Reino: é mencionado somente que era "cristão velho, solteiro, fronteiro, natural da vila de Barcelos do Arcebispado de Braga", além de ser mencionado que era de idade avançada já em 1590. Considerando este último dado, presume-se que ele seria um homem maduro no momento da execução de sua sentença, talvez ocupando a faixa dos quarenta anos de idade, "pouco mais ou menos".

Logo, ele pode ter nascido entre as décadas de 1540 e 1550, o que nos leva a conjecturar a respeito de sua formação: cristão-velho batizado justamente em meio aos últimos três reinados Avis, quando ocorreu a aplicação e intensificação dos projetos de confessionalização e disciplinamento social, Mendonça pode ter sido "moldado" em meio a estes parâmetros, cuja presença na formação dos sujeitos era intensa.

Não se sabe se era letrado, o que, caso o fosse, abriria possibilidades de um aprofundamento maior daqueles processos em sua identidade. Aspecto, por outro lado, conhecido sobre Camacho: filho de mestre-escola, ocupou o mesmo ofício que o pai, tornando-se não apenas produto das imposições identitárias "sacralizantes" em vigor, mas também artífice, conforme foi verificado anteriormente.

Dois termos que surgem ao longo da identificação de Mendonça fornecem discretas, porém valiosas, pistas a seu respeito: era ele "solteiro e fronteiro" no momento em que estava sob escrutínio do Tribunal durante elaboração de sua última sentença. Como solteiro, entende-se que tanto não havia contraído matrimônio ao longo de sua vida como integrava o grupo assim denominado nas partes da

20 ANTT, TSO, IL, Processo 5562, fl.49. 
Índia. Diferentemente dos casados, os solteiros não se estabeleciam, ao menos formalmente, em atividades mercantis ao ponto de se estabelecerem permanentemente em alguma localidade do império. Viviam, por isso, das armas, seja nas embarcações em nome do Estado da Índia, seja nas fortificações que respondiam a este.

Deduz-se, portanto, que Mendonça ocupou a função de homem de armas, o que é reforçado pelo uso do termo fronteiro a seu respeito, sendo fronteiros ou os capitães ou os homens a serviço destes "nas raias e fronteira inimiga". Assim, ele pode ter sido membro dos grupos armados a serviço da Coroa em algum "presídio" de alguma parte do império não especificada. E, ao ser mencionado que serviu como condestável-mor aos soberanos de Barpocha e Bijapur, fica evidente sua atuação intensa em atividades guerreiras, inclusive nas fileiras potencialmente inimigas ao Estado da Índia.

A face guerreira, comum a muitos renegados, não esteve presente somente no caso de Mendonça, sendo compartilhada por Camacho e Toscano. Face presente, sobretudo, nas situações conflitivas nas quais estava mergulhado o Decão de meados do século XVI e princípio do XVII, nas quais tropas mercenárias eram contratadas pelas partes envolvidas. Situações em meio às quais se encontravam os três réus enquanto perambulavam em busca de meios para sobreviver.

Seus caminhos, por sua vez, não respeitavam os limites entre as potestades em disputa, oscilando frequentemente entre elas, sem demonstrar filiações fortes ao ponto de prendê-los a esta ou àquela localidade. O que vale tanto para os sultanatos decanins quanto para os domínios luso-indianos. Para preservarem-se durante suas buscas por segurança e víveres, adotaram diferentes feições, conforme a situação na qual se encontravam exigia. O que, por sua vez, revela possíveis fraturas nos processos de "sacralização" pelos quais foram formados Mendonça e Camacho. Mesmo tendo sido, em maior ou menor grau, modelados de modo a corresponderem a certa expectativa da parte da Coroa e da Igreja portuguesas no que tocava às suas identidades político-religiosas e aos seus comportamentos e moral, ainda assim ambos "fizeram pelo contrário". O que pode ser elucidado pela presença de ambos em meio a situação particularmente frequente no império português: a fronteira.

Tal característica, aliás, marcante em diferentes partes dos domínios lusos ao redor do globo, se fazia frequentemente presente nas áreas sob foco. Apresentando-se mais do que como regiões em que a separação entre cristãos portugueses e demais populações se fazia presente, as áreas fronteiriças situadas entre as possessões portuguesas e demais potestades decanins e guzerates eram pontos de contato entre as realidades luso-indianas e aquelas presentes em seu entorno.

Mendonça, Toscano e Camacho, situados em meio a estas "sombras" territoriais, por força das circunstâncias acima apresentadas, foram levados a circular entre elas. De modo a garantirem sua sobrevivência em meio a este deambular entre realidades políticas, culturais, sociais e econômicas, foram astutos em perceberem, se apropriarem de e mobilizarem códigos para, então, efetuarem suas ações, de modo a obterem meios de subsistência para si.

No entanto, ao mobilizarem os códigos disponíveis nestas áreas de contato (indumentárias, filiações político-religiosas, elaboração de redes parentais via matrimônio), eles o fizeram de modo a 
esvaziarem-nos de certos sentidos agregados a tais linguagens pelas comunidades nas quais elas possuíam ancoragem. Pois sendo tais códigos potentes marcações identitárias públicas, e pelo fato destes três homens renegarem frequentemente os laçoscomunitários que as identidades que assumiam lhes conferiam, os códigos, quando por eles mobilizados, então, não eram muito mais do que isso: código.

Ou seja, um conjunto de sinais que lhes permitia comunicarem-se e, até certo ponto, envolverem-se com aqueles que destes compartilhavam. Mas nada muito além disto, visto que, pelo fato de não criarem vínculos permanentes com as realidades em meio às quais transitavam,os códigos, que nestas indicavam o compartilhamento de identidades coletivas manifestas nas comunidades que os mobilizavam, estavam, quando usados por Mendonça, Camacho e Toscano, de certa forma, vazios da capacidade de indicar algum vínculo efetivo destes com estas realidades.

Esvaziamento que pode ser entendido pelo prisma da "pureza" proposta por Agamben (2007). Pois tais códigos, ao serem mobilizados pragmaticamente pelos homens em questão, o eram não a partir da estrita lógica cultural, social e política das realidades nas quais foram geradas eem meio às quais possuíam sacralidade. Aspecto sacro visível, por exemplo, nas atitudes opressivas e autoritárias por parte tanto das comunidades muçulmanas quanto luso-indianas a respeito da estética de seus membros. Pois, de modo a ser entendido como parte delas, era obrigatória a adoção de aparência que assim indicasse. Aparência, então, restritiva e exclusiva e por isso, sagrada, à qual devia-se atitude reverente por indicar a filiação político-religiosa daquele que a portava.

Contudo, os renegados em questão, dispostos a compreender os códigos estético-identitários das comunidades em que pretendiam ingressar, de modo a operá-los convincentemente ao ponto de serem entendidos como parte delas, anularam para si os sentidos sagrados destes códigos. Pois tomandoos de modo a simplesmente serem admitidos pelas populações muçulmanas com as quais passaram a viver, não necessariamente identificavam-se com estas. Apenas refletiam a imagem que deles exigiam para em seu seio viverem.

Reflexiva e não substancialmente eles operaram estes códigos, os quais "purificaram" dos sentidos conferidos pelas comunidades em questão quanto às filiações identitárias. Uma purificação no sentido agambeniano, pois efetuaram a apropriação dos elementos estéticos que lhes eram impostos de modo a preservarem suas formas, esvaziando-as de seus sentidos primeiros. Executaram, pois, uma “ "profanação" dos códigos estético-identitários que operaram tanto em meio a muçulmanos quanto em meio aos domínios luso-indianos.

Profanação marcada pela transgressão das aparências e filiações que assumiam temporariamente, pois negligenciavam os limites sobre eles impostos pelas potestades às quais se submetiam. Assim, quando a conjuntura os empurrava seja para os sultanatos decanins, seja para os domínios portugueses, eles se metamorfoseavam, sem restringirem-se diante das alteridades que enfrentariam ao ingressarem em nova situação político-religiosa. Pelo contrário, entregavam-se às circunstâncias que oferecessem menos riscos à sua sobrevivência. 
E para tal fim, urgia, por um lado, não serem mais aqueles que estavam sob perseguição, criandose, com isto, a premência de distanciarem-se dos espaços em que a ameaça fosse mais próxima e, também, distanciarem-se dos traços que permitissem sua identificação como aquele a ser capturado. Não é por menos, então, que António Camacho tenha buscado partir para Golconda no princípio de suas jornadas pela Índia. Conforme visto anteriormente, a decisão de partir para este sultanato em específico advinha do fato de este estar situado "para a terra adentro onde menos portugueses vão porque se pesava ele confitente de os portugueses o virem lá andar". ${ }^{21}$

Tanto em seu processo quanto no de Gonçalo Toscano, o distanciamento das terras luso-indianas como meio de escaparem daqueles que nelas os perseguiam serviu como primeira saída deste perigo. Já em meio aos muçulmanos, por certo espaço de tempo conseguiram preservar suas identidades como cristãos, andando "à portuguesa” entre eles. Fato que brevemente se apresentou como não eficiente em garantir-lhes sobrevivência, estando um, António, sob coação para apostatar e outro, Gonçalo, em meio a situação de penúria por ainda apresentar-se como "português".

Compreendendo que a manutenção de suas identidades como súditos cristãos da Coroa lusa não lhes permitiria, em meio aos sultanatos indianos, sobreviver, taticamente apostataram. Pois, entendendo que as "táticas apontam para uma hábil utilização do tempo, das ocasiões que apresenta" (CERTEAU, 2014, p. 96), e tendo eles compreendido que o momento e conjuntura em que se encontravam não lhes favoreciam a permanência no que eram, submeteram-se à transformação de si de acordo com aquilo que os detentores do poder no espaço em que se situavam lhes determinavam.

O que também pode ser percebido em uma das apostasias realizadas por Jorge Mendonça. Estando em Dabul em trajes de cristão acompanhado de uma muçulmana casada, foi capturado pelas "justiças da terra". De modo a delas escapar com vida, alegou ser mouro, adotando mais uma vez a touca e cabaia como vestes e assumindo taticamente a identidade muçulmana para si, "continuando daí por diante com as mesmas cerimônias que antes fazia, no que perseverou por alguns anos". ${ }^{22}$

Ao analisar a trajetória destes três homens, verifica-se, portanto, considerável fluidez identitária a partir das tensas conjunturas em que se encontravam. E a passagem de uma realidade político-religiosa para outra, bem como a metamorfose identitária que realizavam em meio a este trânsito fronteiriço, se dava, segundo o que se pode depreender da documentação analisada, de modo veloz. Afinal, as pressões que os levavam a tais atitudes, permeadas por ameaças às suas vidas, deles exigiam cálculos e decisões rápidas o suficiente para garantirem sua sobrevivência.

Garantia frágil e passageira, aliás. Pois, para alcançarem sucesso em escaparem das forças portuguesas, adentraram por comunidades externas a estas com objetivo de deixar para trás os vínculos que tinham com o império luso, tornando-se fugitivos deste. Entretanto, quando em meio aos muçulmanos, não necessariamente eram considerados parte efetiva das comunidades islâmicas em

21 ANTT, TSO, IL, Processo 4931, fl. 6.

22 ANTT, TSO, IL, Processo 4938, fl.49. 
que passaram a viver, sofrendo suspeição daqueles ao seu redor. O caso de Toscano, por exemplo, nos apresenta tal problema, visto que, após ter apostatado ao apresentar-se ao capitão das forças do "arraial de mouros" localizado nas redondezas de Baçaim e ter adotado a touca e cabaia como sinal de sua passagem à comunidade muçulmana, ainda assim não era digno de confiança.

Decorridos quinze dias de seu serviço como mercenário, foi preso e levado "com o mesmo vestido de português" que usava quando apostatou. Enviado a Ahmadnagar sob suspeita de ser espia dos cristãos em companhia de outros, ficou confinado em uma fortaleza. Lá, mesmo afirmando ser mouro, ficou preso por três meses, período ao longo do qual, segundo consta em seu processo, se tratou sempre como mouro, confessando publicamente que o era, e, comendo com eles, fazia as mesmas cerimônias e rezava as ditas orações que tem dito. ${ }^{23}$

Elemento fortemente presente não só nas relações entre o Estado da Índia e as potestades islâmicas indianas, mas também entre estas, a espionagem, segundo Cruz (1998, p. 182), era uma das ocupações dos renegados. Conhecidos pela volatilidade de suas fidelidades, geravam suspeitas aqueles que, em fuga das autoridades lusas, oferecessem seus serviços tanto de armasquanto de informantes aos sultões decanins e guzerates. A suspeição que sobre eles recaía também derivava do fato de o Estado da Índia lançar mão de espiões espalhados por diferentes partes da Ásia, de forma a obter informações adiantadamente e, assim, garantir estratégias eficazes em tempo.

Percebe-se, portanto, que a fluidez das filiações e identidades dos casos dos renegados que aqui estão sob foco poderia também decorrer das pressões a que estariam submetidos, mesmo nas áreas em que buscassem refúgio. Sendo eles homens fronteiriços e oscilantes e havendo conhecimento da parte das lideranças islâmicas de que poderiam as forças lusitanas, através destes "homens das sombras", infiltrarem-se e obterem vantagens estratégicas com isso, a suspeita, então, sobre os renegados pesava consideravelmente. E isto, por sua vez, tanto nas terras sob jurisdição islâmica, quanto nas subjugadas por Portugal, pois renegavam sua submissão a este.

Assim, seu caráter fluido pode ser considerado fruto da necessidade de transformarem-se a partir das alterações conjunturais que lhes fossem ameaçadoras. Tais transformações, ademais, avançavam sobre as próprias definições do sujeito, fossem-lhes impostas ou não. A exemplo disto, temos a questão do nome. Os três casos sobre os quais nos debruçamos apresentam em comum o fato de terem tido os réus seus nomes alterados aquando de sua passagem ao Islã.

Infelizmente, os casos de Mendonça e Toscano não apresentam os outros nomes que receberam ou adotaram ao longo de suas jornadas quando apostataram, sendo mencionado somente que tomaram "nome de mouro". Já Camacho, segundo seu processo, recebeu diferentes nomes: ao apostatar em Golconda, por volta de 1564, teria recebido o nome de Calir. Cerca de três a quatro anos mais tarde, em fuga das autoridades lusas, em região que é denominada no documento analisado como Serra do Nyrão, afirmou à mesa inquisitorial que, mais uma vez "sob a pele" de muçulmano, tomou moxara de um capitão

23 ANTT, TSO, IL, Processo 4938, fl.8-9. 
abexim de nome Cyde Rana Reenrulaa. A serviço deste por cerca de dois meses, andou à mourisca e assumiu onome de Aguafrangui.

Quanto ao momento de seu primeiro nome de mouro, Calir, é mencionado em seu processo que, durante o período em que assim ficou conhecido na comunidade muçulmana em que viveu em Golconda por cerca de nove meses, variavam as maneiras pelas quais se identificava. Em algumas circunstâncias era chamado por este nome, em outras por António Camacho, o que revela sinais de uma possível identificação fluida enquanto esteve neste sultanato. Talvez fosse ainda chamado pela alcunha portuguesa por ser entendido como um estranho ao local em que passara a viver, sendo marcado seu caráter externo à população que o recebera, quiçá com desconfiança.

Ou tenha adotado ambas as formas de se identificar, variando-as de acordo com seus interlocutores. Assim, em situações em que deveria corresponder à expectativa de que havia de fato se tornado "mouro", assumia a persona Calir: homem muçulmano praticante dos ritos que lhe fossem condizentes como tal, bem como deveria aparentar que assim o era, apresentando- se à comunidade com a estética por esta exigida sobre aqueles que fossem seus membros.

Outra hipótese, contudo, auxilia na compreensão de sua dupla nomeação: por um lado, como Calir, ele mais profundamente se inseria e era melhor aceito entre muçulmanos. Por outro, como António, ignorando o possível rechaço por parte daqueles, poderia ele, através deste outro nome e persona, envolver-se com pessoas de fora da comunidade na qual estava abrigado. Outros "portugueses", talvez também sob a condição de renegados, por exemplo, que estivessem de passagem por Golconda.

Em seu processo são mencionados outros homens nesta condição que lhe prestaram auxílio material, o acompanharam em suas viagens pelo Decão ou lhe aconselharam a tomar certas decisões, caso de João Perez. António Guarcão foi um dos que o auxiliaram: nomeando-se a ele como António Camacho e revelando suas intenções de retornar à "terra dos cristãos", conseguiu acompanhá-lo a Goa, pois fazia parte de comitiva do embaixador do Cotamaluqo.

Assim, revelar-se a Guarcão como cristão que, segundo seu processo, havia se arrependido de ter vivido como mouro e desejava retornar aos domínios portugueses, pode ter lhe garantido o apoio necessário para efetuar a longa e perigosa viagem de Golconda até Goa junto à embaixada do sultão. Não é mencionado se Guarcão havia apostatado, ainda que fosse membro de comitiva oficial do sultanato. Seu "sobrenome", no entanto, pode indicar a ocupação, de fato, de algum posto de comando no Cotamaluqo. Pois é possível que, não sendo Guarcão nome português, mas a versão lusitana de alguma nomeação com o sufixo khan, o qual indicava posições de liderança nas áreas muçulmanas indianas e da Ásia Central, possivelmente António Guarcão, então, detivesse algum poder em Golconda.

Ao prestar auxílio a Camacho, um renegado talvez arrependido, abre-se a possibilidadede que tenha com este se identificado, pois poderiam compartilhar elementos identitários que favorecessem a comunicação e a interação entre eles. Fatores que também podem ter contribuído para outra face da ajuda fornecida por Guarcão: a possibilidade de ter exigido algo de Camacho que não foi revelado por sua fala ao tribunal quando da elaboração de seu processo. 
Depreende-se, então, desta passagem de seu processo a respeito de sua "dupla identidade" entre os anos de 1564 e 1565, que o fato de ter apostatado e ter assumido novos traços identitários de modo a ser aceito pela comunidade muçulmana na qual passou a viver ao longo dos meses em que esteve em Golconda não excluiu a mobilização de sua identidade anterior. Assim, diante da Umma, Camacho, compreendendo a necessidade de alterar-se de modo suficientemente convincente ao ponto de ser absorvido por aqueles que o receberam, entregou-se à força das circunstâncias: obteve outro nome, outra aparência, praticou outros ritos e teve seu próprio corpo intimamente alterado.

No entanto, ao menos segundo aquilo que consta como seu depoimento frente à mesa inquisitorial, da mesma forma como assumiu uma nova persona, Calir, a outra, aquela que consigo havia trazido como cristão, era também mobilizada quando a conjuntura lhe favorecia o ressurgir. Assim, o "ser António Camacho" (renegado e oscilante) conviveu com o "ser Calir", o neófito muçulmano em Golconda. Ambos, ao longo de nove meses, "coabitaram” o mesmo corpo, sobre o qual, então, incidiram distintas e dialogantes identidades.

Diálogos em que a voz de uma se sobrepunha à da outra aquando da necessidade de alterar-se segundo as circunstâncias. Logo, um pragmatismo "profanador" parece ter movido este homem a metamorfosear-se ao longo de sua passagem pelo Decão. Pragmatismo marcado pela manipulação tática dos códigos identitários presentes nas comunidades pelas quais circulou ou diante de pessoas que poderiam beneficiá-lo ao adotar uma ou outra identidade. Códigos que, "purificados" de seus sentidos identitários originais, estavam liberados para manipulação a partir das necessidades de seu usuário, no caso, Camacho.

Portanto, diante do sultão de Golconda, ainda que fosse cristão-velho e tenha sido formado em ambiente consideravelmente "sacralizante" no que toca à construção identitária, a Lisboa de meados dos Quinhentos, o então Camacho, calculando as possibilidades de sobrevivência, submete-se à alteração de si, apostata e torna-se o muçulmano Calir. Mais tarde, já diante de possibilidades de retornar às terras luso-indianas por motivos, segundo seu processo, conscienciais, retoma sua anterior identificação, rompendo com as restrições identitárias que lhe foram impostas quando muçulmano e apresentando-se a outro "português"como António Camacho.

Operando cálculos cujos fatores consistiam nas conjunturas em que se encontrava e nos códigos identitários que seria capaz de mobilizar em benefício próprio, Camacho parece ter tido como expectativa de resultado sua sobrevivência acima de tudo. Para tal fim, abriu mão de laços, seja com a comunidade em meio à qual nasceu e foi formado, com o império ao qual originalmente estava submetido, seja com as comunidades que viessem a abrigá-lo ao longo de suas viagens e fugas.

Logo, de modo a circular entre estas realidades, lançava mão do recurso da "profanação" de si: submetendo-se a distintos elementos distintivos e identitários, ele absorvia e manipulava características que deveriam ser expostas aos grupos em meio aos quais estas fossem condizentes com aquilo que dele era esperado. Contudo, vista sua capacidade de transformação, tais características, quando por ele mobilizadas estavam "puras" de seus significados relacionais. Camacho as "vestia" provavelmente tendo 
em mente a possibilidade de, caso necessário, despir-se delas e tornar-se outro de acordo com seus recursos identitários. Utilizou-os, pois, de modo "profano" por conferir uso livre dos sentidos restritivos aos quais tais elementos estavam originalmente submetidos.

Tal fato pode ser observado em outra das identidades que assumiu e que, antes, fora citada: Aguafrangui. Conforme mencionado, Camacho, por volta de 1567, mais uma vez em fuga das autoridades lusas, partiu para região designada na fonte como Serra do Nyrão e, hoje, provavelmente localizada próxima a Mumbai. Lá, apresentando-se à liderança muçulmana local, pediu por moxara. Para tal, no entanto, não se apresentou como "português", mas, "vestido à mourisca", com o "nome de mouro" Aguafrangui24.

Novamente Camacho apresentou à Mesa que, "por ter necessidade", submeteu-se aos "costumes mouros". Ou seja, para adquirir o meio com o qual obteria insumos para sua sobrevivência, a moxara, curvou-se ao senhor muçulmano local. Mais uma vez, então, ele, pragmaticamente, "profanou" sua identidade e assumiu características estranhas às suas origens e formação "sacralizantes" cristãs portuguesas. Há, no entanto, neste processo, um sinal de manipulação dos códigos identitários de modo particularmente interessante: o documento apresenta Camacho se nomeando e não sendo nomeado como Aguafrangui.

Tal detalhe não pode ser desmerecido. Antes de sua chegada à Serra do Nyrão, Camacho, segundo um de seus depoimentos à Inquisição de Goa, ao ser despachado aquando da segunda execução de suas penas, em 1567, pela qual havia sido condenado às galés por três anos em Portugal, ele, em companhia de outros presos, escapa da nau que os levaria para o Reino para cumprirem suas penas. Alegando aos seus companheiros de fuga que obteria para eles, junto ao sultão de Ahmadnagar, moxaras e que sabia a língua local, bem como já conhecia a terra, conseguiu deles apoio na fuga, ainda que boa parte do grupo tenha partido para outros cantos da Índia.

Neste período entre esta fuga e sua entrega espontânea ao Santo Ofício, cerca de um ano e meio depois, Camacho afirmou à Mesa que teria perambulado por Bijapur, Cambaia, Ahmadnagar e Golconda, buscando, inclusive, partir para Bengala, o que não o fez por esta, à época, estar sob poder dos afegãos. Ao longo deste tempo "andava às vezes vestido à mourisca e às vezes à portuguesa e perguntando-lhe algumas vezes alguns mouros se era mouro dizia que sim por se congraçar com eles e lhe fazerem alguns bens". ${ }^{25}$

A passagem acima prossegue para o momento em que afirma ter partido para a Serra do Nyrão, onde assumiu a identidade de Aguafrangui. Fica nítido, portanto, que, ao longo de seus relatos aos inquisidores, Camacho demonstrou ter acumulado conhecimentos a respeito das diferentes regiões e potestades pelas quais passou durante os anos em que viveu como andarilho pela Índia. Revelando conhecer alguma das línguas locais, tornando-se capaz de ser identificado como mouro por outros a partir de indumentária e da apresentação de traços condizentes com tal identidade político-religiosa, ele

${ }^{24}$ ANTT, TSO, IL, Processo 5562, fl.67.

25 ANTT, TSO, IL, Processo 5562, fl.67.

Pol. Hist. Soc., Vitória da Conquista, v. 20, n. 1, p. 23-44, jan.-jun. 2021. ISSN 2236-8094 
mostrou-se hábil na capacidade de circular em meio às comunidades muçulmanas do Decão, assim como para obter ganhos destas.

Assim, ao se nomear como Aguafrangui ao abexim Cyde Rana Reenrulaa para obter tenças, não o fez de modo incauto. Pelo contrário: calculando as maneiras mais efetivas de obtê-las, assume-se mais uma vez como muçulmano, inclusive com nome condizente a esta condição. Nome, aliás, que pode revelar uma curiosa construção de si: o sufixo frangui pode ter sido por ele incluído de modo a ser entendido não como um nativo ou como membro de alguma comunidade específica muçulmana, mas como proveniente do grupo assim denominado. Ou seja, como um homem cuja identidade estava associada a grupo étnico-cultural ligado à pirataria e ao uso de armas de fogo cobiçadas nos mercados de guerra indianos, bengaleses e de outras partes ao redor do Índico. Talvez, então, Camacho, apresentandose como frangui à liderança local, poderia estar calculando as possibilidades de obtenção de ganhos mediante a apresentação de si mesmo como pretendente a membro das tropas do abexim. Colocava-se, desta forma, novamente sob as vestes de mercenário, inclusive articulando elementos que o inserissem de modo a ser valorizado pela lógica identitária local: como muçulmano frangui.

Percebe-se, portanto, que Camacho, portador de conhecimentos úteis e práticos à sua sobrevivência em meio ao Decão, eficientemente mobilizou características presentes nos ambientes pelos quais circulou para criar táticas de sobrevivência em localidades cujas populações dele exigiam considerável plasticidade para ser por elas aceito. Tamanha adaptabilidade, por outro lado, revela sua capacidade de mobilidade, denotando sua não fixidez às áreas nas quais viveu.

Fluido, então, Camacho, já como Aguafrangui dispunha de um rol de recursos identitários dos quais poderia fazer uso de acordo com as circunstâncias. Não se prendendo a nenhum deles em específico, mas entre eles oscilando, adotou atitude de "purificação" dos sentidos que neles residiam. Ou seja, ao se tornar ora "mouro", ora cristão, ao que parece, pouco lhe importavam os significados conferidos aos ritos que seguia, às vestes que usava e aos nomes que lhe eram impostos ou dos quais deliberadamente fizesse uso. Desde que tais elementos lhe fornecessem meios de sobrevivência e segurança, ele deles taticamente lançava mão.

Tal "purificação" tática de sentidos dos elementos identitários, por sua vez, nos leva a considerar também que a própria identidade de Camacho, sob constante cálculo e manipulação e, por isso, fluida, não estava adstrita a determinada realidade histórica, cultural, social e política. Era aberta às circunstâncias, tornando sua existência contrária à rigidez em meio à qual foi formada, ao longo do período em que viveu em Lisboa. Lá, sob a égide dos projetos de confessionalização de disciplinamento social, inclusive atuando provavelmente em favor disto, sob o papel de mestre-escola, Camacho, até partir para a Ásia, correspondia às expectativas que sobre ele incidiam, oriundas da Coroa e da Igreja.

Ao longo dos anos na Índia, entretanto, não somente abandonou suas filiações político-religiosas com o império português ao tornar-se, por algumas vezes, muçulmano e submetido aos sultões decanins. Mais do que isso: oscilou entre as personas distintas que lhe compunham, assumindo-se não necessária e 
somente como homem convertido ao Islã. Mas ora como muçulmano convertido à força, ora como muçulmano frangui, ora como renegado cristão e ora como cristão arrependido.

Uma existência múltipla, então. Multiplicidade construída a partir de sua localização em meio a fronteiras de diversas ordens. Fronteiras político-religioso-culturais entre domínios de distintos grupos étnico-confessionais que favoreceram tanto a sua entrada quanto a dos demais renegados aqui analisados em situações de "contágio" a partir de suas necessidades de fuga. A qual, direcionada a ambientes externos àqueles de onde partiam seus algozes, ofereciam possibilidades de ser para além daquelas presentes em suas realidades originais. Assim, o Decão ofereceu a estes homiziados a possibilidade de adquirirem, pela experiência da alteridade, a capacidade de transmutarem-se identitariamente.

Transmutação marcada por necessidades prementes de sobrevivência, ela foi operada em meio aos processos aqui identificados como "profanadores". Pois, ao ingressarem nas paragens exóticas que lhes ofereceram tanto abrigo quanto "contágio" com realidades distintas, tiveram que nelas operarem de modo livre os códigos identitários destas que lhes garantiriam acesso à manutenção de suas vidas. Visto que, mesmo nestas, correram perigos e tendo em mente que quase permanentemente eram fugitivos do Estado da Índia, a urgência de transformarem-se em outros para escaparem das ameaças em seus encalços os levou a não se limitarem a uma específica persona.

Pelo contrário. Como visto com maior riqueza de detalhes no caso de Camacho, assumir-se "outros", de acordo com as circunstâncias, foi o garante de uma sobrevivência mais longa. Um assumir que dependia da compreensão, profanação e mobilização dos códigos identitários que aprendeu ao longo de suas viagens pelo Decão. Profanação presente nos outros casos, pois fica evidente o recurso à transgressão de seus limites identitários ao também assumirem taticamente novas personas, vividas, logo, usadas, ao sabor das circunstâncias.

Uma transgressão que, marcada pela negligência quanto às restrições que lhes foram impostas durante suas formações sacralizantes como súditos católicos portugueses (sobretudo quanto a Camacho e Mendonça), teve como objeto suas próprias existências. As quais, lançadas en uma multiplicidade de possibilidades de serem, constituíram-se de modo profano por não mais limitarem-se a imposições externas, mas por serem criadas e recriadas a partir da purificação de códigos identitários a que tiveram acesso e, com isso, ampla manipulação tática de suas identidades, absorvendo e operando-os de acordo com suas próprias necessidades.

\section{FONTES}

ANTT, TSO, IL, 28, Processo 5562 (António Camacho). Disponível em: https://digitarq.arquivos.pt/viewer?id=2305591

ANTT, TSO, IL, 28, Traslados de sentenças de algumas pessoas despachadas na Inquisição de Goa, Processo 4938, fl. 85-99. Sentença de Dom António Ramirez. Disponível em: https:/ / digitarq.arquivos.pt/viewer?id=2304940. 
ANTT, TSO, IL, 28, Processo 5562, fl. 54-63. Depoimento de Gonçalo Guedes de Revoredo. Disponível em: https://digitarq.arquivos.pt/viewer?id=2305591.

ANTT, TSO, IL, 28, Processo 4931 (Gonçalo Toscano). Disponível em: https:/ / digitarq.arquivos.pt/viewer?id=2304933.

ANTT, TSO, IL, 28, Traslados de sentenças de algumas pessoas despachadas na Inquisição de Goa, Processo 4938, fl.103-105. Sentença de Jorge Cardozo de Mendonça. Disponível em: https://digitarq.arquivos.pt/viewer?id=2304940.

\section{REFERÊNCIAS}

AGAMBEN, G. Profanações. São Paulo: Boitempo, 2007.

CERTEAU, M. de. A invenção do cotidiano. 1. Artes de fazer. Petrópolis: Vozes, 2014.

CRUZ, M. A. L. Degredados e arrenegados portugueses no espaço índico, nos primórdios do século XVI. Textos de História, v. 6, n. 1 e 2, p. 169-184, 1998.

FOUCAULT, M. Prefácio à transgressão. In: FOUCAULT, M. Estética: Literatura e Pintura, Música e Cinema. Rio de Janeiro: Forense Universitária, 2009. p. 28-46.

LIPINER, E. Santa Inquisição: terror e linguagem. Rio de Janeiro: Documentário,1977.

PALOMO, F. A Contrarreforma em Portugal, 1540-1700. Lisboa: Livros Horizonte, 2006. 